\section{Penguatan Kelembagaan Dalam Implementasi Program Sanitasi Berbasis Masyarakat}

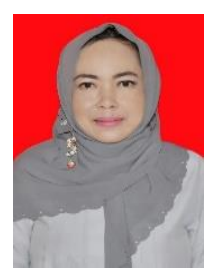

\section{Aulia Noorjenah}

Lahir di Banjarmasin pada tanggal 20 November 1974, Sarjana (S1) Teknik Sipil Universitas Lambung Mangkurat, dan bekerja di Satker PSPLP Prov. Kalimantan Selatan.buletinppi@ulm.ac.id
Sanitasi yang sehat adalah sebuah kebutuhan pokok bagi manusia dan lingkungan, sebab kondisi sanitasi mencerminkan baik atau buruknya kesehatan manusia dan lingkungan setempat.Program SANIMAS adalah program perbaikan sanitasi masyarakat dari Kementerian PUPR yang dikendalikan oleh Satuan Kerja PSPLP dan Fasilitator Provinsidi Provinsi seluruh Indonesia.Pelaksanaan Program SANIMAS ini direncanakan, dilaksanakan, dimanfaatkan, dan dipelihara oleh Masyarakat dengan didampingi oleh Tenaga Fasilitator Lapangan (TFL) Teknik dan Pemberdayaan dalam satu tim. Program ini dilaksanakan setiap tahun selama 10 (sepuluh) bulan secara swakelola oleh Satuan Kerja PSPLP dengan dibantu oleh Fasilitator Provinsi.

www.buletinppi.ulm.ac.id

\section{Pendahuluan}

Sanimas (Sanitasi Berbasis Masyrakat) merupakan program yang digagas oleh pemerintah untuk meningkatkan akses masyarakat terhadap sarana dan prasarana sanitasi. Sebagaimana yang kita ketahui bersama, bahwa sampai dengan saat ini masih banyak masyarakat yang melakukan buang air besar sembarangan (BABS). Menurut data yang dihimpun pada tahun 2013, lebih dari 30\% masyarakat di Kalimantan Selatan masih melakukan BABS. Hal ini tentu sangat mengancam kesehatan lingkungan, yang pada akhirnya menurunkan kualitas hidup masyarakat.

Untuk itu maka pemerintah menggagas program Sanimas. Tujuannya untuk meningkatkan akses masyarakat terhadap sarana dan prasarana sanitasi, sehingga perilaku hidup bersih masyarakat dapat ditingkatkan. Berbagai bentuk aplikasi prasarana dan sarana dapat diterapkan, yaitu IPAL komunal dan MCK+. Dengan adanya Program Sanimas perilaku BABS dapat ditekan atau bahkan dihapuskan.

\section{Realisasi Kegiatan}

Salah satu kegiatan dalam pelaksanaan program Sanimas ini adalah penguatan kelembagaan. Tahap dimana Satuan Kerja Pegembangan Sistem Penyehatan Lingkungan Permukiman (PSPLP) Provinsi Kalimantan Selatan sebagai satuan kerja pembina dari Kementerian Pekerjaan Umum melakukan pembinaan, pembangunan pengetahuan dan keterampilan terhadap kelompok masyarakat penerima manfaat Sanimas dengan didampingi oleh Tenaga Fasilitator Lapangan (TFL) Teknik dan Pemberdayaan dalam satu tim. Program ini dilaksanakan setiap tahun selama 10 (sepuluh) bulan secara swakelola oleh Satuan Kerja PSPLP dengan dibantu oleh Fasilitator Provinsi, yang pelaksanaan seluruh kegiatan programnya dimulai dari sosialisasi, pembangunan dan pemeliharaan dari bulan Maret sampai bulan Desember pada setiap tahunnya.
Penguatan kelembagaan ini bertujuan untuk memberikan pemahaman yang utuh dan menyeluruh akan tugas pokok Kelompok Swadaya Masyarakat (KSM). KSM sebagai wadah masyarakat penerima manfaat Sanimas dapat memahami dan bertanggungjawab dalam menyusun dan menjalankan anggaran dasar dan anggaran rumah tangga KSM yang telah mereka tetapkan. KSM sebagai pengelola kegiatan diharapkan akan berlaku transparan dan akuntabel dalam mengelola anggaran dan administrasi. KSM sebagai wadah masyarakat juga diharapkan dapat menjalankan fungsi sebagai perintis lapangan/fasilitator sebagai pelaku hidup bersih dan sehat (PHBS).

Dalam kegiatan penguatan kelembagaan ini perlu disampaikan pula pemahaman dan pengetahuan mengenai prinsip-prinsip dasar pengelolaan air limbah domestik dan beberapa peraturan pemerintah tentang air limbah domestik. Kelompok Masyarakat sebagai perencana, pelaksana, dan pengawas pekerjaan fisik mampu memahami spesifikasi teknis, membaca gambar teknis dan mengaplikasikan pekerjaan fisik dari Detail Engineering Design maupun rencana anggaran biaya yang mereka buat sendiri dengan dibantu konsultan pendamping.

Detail kegiatan ini adalah dengan penyelenggaraan kegiatan Pelatihan KSM Sanimas Provinsi Kalimantan Selatan selama 3 (tiga) hari yang diselenggarakan sebelum penandatanganan kontrak antara KSM dengan pihak Satker untuk memulai kegiatan pembangunan. Materi yang disampaikan dalam pelatihan ini adalah sebagai berikut :

1. Pekerjaan Swakelola

2. Pengorganisasian, Tugas dan Fungsi KSM

3. Partisipasi dan Sharing Pengalaman KSM

4. Mekanisme Pelaporan dan Tanggung Jawab KSM

5. Pemahaman Perilaku Sanitasi Masyarakat di Kabupaten/Kota se Kalimantan Selatan

6. Peranan dan Partisipasi Pemerintah Kabupaten Banjar dalam Program SANIMAS

7. Dasar-Dasar Pengelolaan Air Limbah, dan Syaratsyarat konstruksi 
8. Kunjungan Lapangan

9. Rencana Kerja dan Tindak Lanjut

Adapun capaian hasil yang diperoleh melalui kegiatan ini yang telah dapat di data secara kualitatif adalah :

1. Terjadinya peningkatan perubahan perilaku yang telah menyadarkan masyarakat akan pentingnya PHBS (Pola Hidup Bersih dan Sehat)

2. Peningkatan derajat kesehatan masyarakat

3. Peningkatan kualitas lingkungan hidup di sekitar masyarakat.

Pencapaian target kegiatan secara kuantitatif akan dinilai pada tahun berikutnya dan akan dilakukan evaluasi setiap tahun untuk perbaikan program di masa mendatang. Kemungkinan dalam mencapai target Direktorat Jenderal Cipta Karya untuk 100\% akses sanitasi di tahun 2019 belumlah terpenuhi, akan tetapi dengan kerja keras dan upaya sungguh-sungguh, hal tersebut tidaklah mustahil untuk diwujudkan.

\section{Kesimpulan}

Program SANIMAS (Sanitasi Berbasis Masyarakat) adalah suatu usaha penyehatan manusia dan lingkungan dengan pembenahan sanitasi melalui Pemberdayaan Masyarakat (dari dan untuk masyarakat) sehingga tumbuh rasa memiliki oleh masyarakat terhadap fasilitas yang dibangun oleh Pemerintah, dan semua kegiatan dari perencanaan, pelaksanaan, dan pemeliharaan dilaksanakan oleh Masyarakat dengan didampingi oleh Fasilitator Lapangan Teknik dan Pemberdayaan.

Kegiatan penguatan kelembagaan merupakan aspek penting yang harus diperhatikan mengingat kelompok masyarakat ini merupakan ujung tombak dalam penerapan program dan kebijakan pemerintah agar dapat diterima dan diwujudkan di tingkat masyarakat

\section{Ucapan Terimakasih}

Ucapan terima kasih ditujukan kepada:

1. Allah SWT atas segala bimbingan, karunia, dan nikmat NYA ;

2. Keluarga Penulis atas segala dukungannya baik berupa moril maupun materil ;

3. Kasatker PSPLP Prov. Kalimantan Selatan beserta seluruh Staf, atas segala ilmu dan bimbingannya ;

4. Ketua Prodi PPI Universitas Lambung Mangkurat beserta seluruh Dosen, Dosen Penguji, dan Staf, atas segala dukungan, bimbingan, dan ilmunya ;

5. Rekan-rekan Mahasiswa Program Profesi Insinyur ULM.

\section{Referensi}

1 "KLH Melakukan Pemantauan Kualitas Air Sungai di 33 Provinsi", http://www.menlh.go.id/klhmelakukan-pemantauan-kualitas-air-di-33-provinsi/, diakses 16 Januari 2017.
2 "Sanitasi Buruk Menghambat Potensi Pertumbuhan Indonesia", http:// www.worldbank.org/in/news/pressrelease/2013/10/28/Poor-Sanitation- ImpedesIndonesia-8217-s-Growth- Potential, diakses 16 Januari 2017.

3 Badan Penelitian dan Pengembangan Kesehatan Kementerian Kesehatan RI, 2013, Riset Kesehatan Dasar Tahun 2013. 